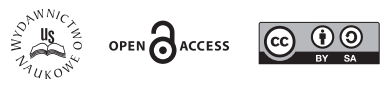

„Analiza i Egzystencja” 56 (2021), 95-118

ISSN (print): 1734-9923

ISSN (online): 2300-7621

DOI: $10.18276 /$ aie.2021.56-05

ARTYKUŁY

\title{
MAŁGORZATA WRZOSEK
}

ORCID: 0000-0002-7136-3365

\section{TINNITUS. ANALIZA WYBRANYCH MODELI FANTOMOWEGO DŹWIĘKU}

Słowa kluczowe: szumy uszne, tinnitus, fantomowy dźwięk, modele tinntusu, zespół zaburzeń wywołanych szumami usznymi (ZZWSU)

Keywords: tinnitus, phantom sound, models of tinnitus, tinnitus disorder

Szumy uszne (tinnitus, z łac. tinnire - dzwonić) to doświadczenie polegające na wrażeniu percepcji często uciążliwego dźwięku (np. szumu, buczenia,

* Małgorzata Wrzosek - dr, kognitywistka, adiunkt w Uniwersytecie Szczecińskim, zainteresowana głównie psychoakustyką i interakcją wzrokowo-słuchową, odbyła staże m.in w Uniwersytecie i Szpitalu Uniwersyteckim w Zurychu, Uniwersytecie w Bergen, Śródziemnomorskim Instytucie Badań i Leczenia Tinnitusu w Marsylii, Laboratorium Neuronauki Poznawczej w Uniwersytecie Aix-Marseille oraz Laboratorium Języka i Emocji Wolnego Uniwersytetu w Berlinie.

Address for correspondence: Uniwersytet Szczeciński, Instytut Filozofii i Kognitywistyki, Krakowska 71-79, 71-017 Szczecin, Poland. E-mail: malgorzata.wrzosek@ usz.edu.pl.

1 W polskiej nomenklaturze opisywane zjawisko występuje pod nazwą ,,szumy uszne”. Postuluję wprowadzenie do użycia termin ,tinnitus” spotykany w innych językach. Nazwa „szumy uszne” może mylnie sugerować, że dźwięki słyszane przez pacjentów przyjmują formę wyłącznie szumów, tymczasem szumy uszne o innym charakterze, np. tonalnym 
pisku) przy braku bodźca go wywołującego (Jastreboff, Hazell, 1993). Wrażenie to jest wyłącznie efektem działania układu nerwowego i niekiedy precyzyjniej bywa określane mianem szumów usznych subiektywnych. Niektórzy badacze wskazują także na istnienie tinnitusu obiektywnego, który w określonych przypadkach może zostać usłyszany również przez inną osobę (Jastreboff, Hazell, 2004). Tego typu doświadczenie spowodowane jest dźwiękami generowanymi w ciele, np. turbulencją przepływu krwi lub specyficznymi skurczami mięśni. Szumy uszne bywają także określane mianem fantomowej percepcji słuchowej (Jastreboff, 1990; Weisz, Hartmann, Dohrmann, Schlee, Noreña, 2006; De Ridder, Elgoyhen, Romo, Langguth, 2011, Schaette, Turtle, Munro, 2012; Sedley, Friston, Gander, Kumar, Griffiths, 2016).

Celem artykułu jest przegląd wybranych modeli mechanizmów powstawania słuchowej percepcji fantomowej, czyli szumów usznych, rozpatrywanych w dwóch kategoriach - tinnitusu (percepcja szumów usznych) i zespołu zaburzeń wywołanych szumami usznymi (ZZWSU, percepcja tinnitusu połączona z cierpieniem) ${ }^{2}$. W pierwszej kolejności, w części 1, omówiono charakterystykę tinnitusu jako zjawiska opisywanego w praktyce klinicznej. Następnie, w części 2, przedstawiono zwierzęcy (skonstruowany na podstawie badań na zwierzętach eksperymentalnych), fizjologiczno-behawioralny model tinnitusu, który dostarczył uzasadnienia dla konstruowania zwierzęcych modeli zjawiska. Modele zwierzęce szumów usznych umożliwiły wgląd w procesy zachodzące na pierwszych piętrach przetwarzania informacji słuchowej, stając się podstawą konstrukcji modeli neurofizjologicznych, które przedstawiono w części 3. Modele te w większości za korelat tinnitusu zgodnie wskazują podwyższoną spontaniczną aktywność komórek nerwowych i/lub prawdopodobnie powiązaną z nią synchroniczność neuronalną. Część 4 to przegląd wybranych opracowań uwzględniających zaangażowanie procesów poznawczych i psychologicznych doprowadzających do

(brzmiące jak pojedynczy ciągły ton, pisk) występują równo często lub nawet częściej (Turner, 1990; Pantev, Okamoto, Teismann, 2012; Hauptmann i in., 2015; Williams, Hauptmann, Patel, 2015; Stein i in., 2016; Chung, Byun, Lee, Park, Jang, 2017). Termin „tinnitus” będzie stosowany zamiennie z jego polskim odpowiednikiem.

2 Angielski odpowiednik terminu to tinnitus disorder, w którym towarzyszące percepcji tinnitusu cierpienie obejmuje emocjonalny dystres, zaburzone funkcjonowanie poznawcze czy też pobudzenie autonomiczne. Czynniki te prowadzą do zmian na poziomie behawioralnym i niepełnosprawności funkcjonalnej (definicja za: De Ridder i in., 2021). 
uformowania się ZZWSU, czyli percepcji tinnitusu powiązanej z cierpieniem. Zaprezentowany przegląd modeli pokaże, że zarówno tinnitus, jak i zespół zaburzeń wywołanych szumami usznymi to interdyscyplinarne problemy badawcze i kliniczne, co może przemawiać za podjęciem tego tematu przez kognitywistykę. W podsumowaniu artykułu zaproponowano umieszczenie dyskusji nad mechanizmami i naturą tinnitusu w kontekście filozoficznych i kognitywistycznych rozważań nad przedmiotem percepcji słuchowej.

\section{Tinnitus z punktu widzenia praktyki klinicznej}

Praktyka kliniczna pokazuje, że charakterystyka tinnitusu może znacząco różnić się między pacjentami - szumy uszne mogą być słyszane w jednym, dwojgu uszu lub wewnątrz głowy, być dźwiękiem stałym lub przerywanym o różnej głośności, opisywanym w kategoriach niskich lub wysokich częstotliwości. Tinnitus może być postrzegany bez przerwy lub pojawiać się co jakiś czas, u części pacjentów podlegać maskowaniu (,zagłuszaniu” przez inny dźwięk) (Feldmann, 1971). W przypadku niektórych pacjentów szumy uszne mogą być modulowane poprzez manipulacje odcinkiem szyjnym kręgosłupa (np. uciskanie okolic szyi), wykonywanie ruchów szczęką czy poruszanie oczami (Sanchez, Rocha, 2011).

Chroniczne szumy uszne są częstą przypadłością, dotyczą w przybliżeniu 10\% ogólnej populacji (Langguth, Landgrebe, Kleinjung, Sand, Hajak, 2011). Skarżyński i współpracownicy w 2000 roku przedstawili szacunki dotyczące częstości występowania szumów usznych w populacji polskiej (osoby dorosłe). Niemal 1,6 mln osób (niemal 5\% populacji) stanowiły osoby, dla których szumy uszne były stanem chronicznym, dla 4\% z nich przyjmując poważnie dokuczliwą formę (Skarżyński, Rogowski, Bartnik, Fabijańska, 2000). Problem ten może dotyczyć również dzieci (Bartnik i in., 2012; Piotrowska, Raj-Koziak, Lorens, Skarżyński, 2015).

Tinnitus może znacząco obniżyć jakość życia, prowadząc nawet do samobójstw (Jastreboff, Hazel, 2004). Stosunkowo często współwystępuje z zaburzeniami snu (Crönlein in., 2016), lękiem (anxiety) (Udupi i in., 2013; Kehrle i in., 2016), a także depresją (Langguth, Landgrebe, Kleinjung, Sand, Hajak, 2011). Towarzyszyć mu mogą także inne zaburzenia związane np. z percepcją głośności: hiperakuzja (obniżona tolerancja dźwięków), 
mizofonia (niechęć do konkretnych rodzajów dźwięków), fonofobia (lęk przed dźwiękami) czy syndrom „eksplodującej głowy” (doświadczenie pojawiające się głównie podczas snu lub senności polegające na usłyszeniu głośnego i nagłego hałasu, który wydaje się pochodzić z wnętrza głowy) (Jastreboff, 2007; Møller, 2011b).

Etiologia szumów usznych jest zróżnicowana. Najczęściej związane są one z ubytkiem słuchu (m.in.: Martines, Bentivegna, Martines, Sciacca, Martinciglio, 2010; Baracca, Del Bo, Ambrosetti, 2011; Henderson, Bielefeld, Lobarinas, Tanaka, 2011; Kleinjung, 2011; Møller, 2011a; Schecklmann i in., 2012), mogą być także konsekwencją silnego stresu, nadciśnienia, ekspozycji na duży hałas (np. wystrzał z broni palnej), a także nadużycia aspiryny (Jastreboff, Hazell, 2004). Zjawisko to jest jednym z trzech głównych objawów choroby Meniere'a (obok zawrotów głowy i niedosłuchu, Ying, Arriaga, 2011) i może być następstwem zapalenia nerwu przedsionkowo-ślimakowego (May, Ramachandran, Cacace, 2011), nerwiaka nerwu słuchowego (Raj-Koziak i in., 2003), choroby naczyniowo-mózgowej (Láinez, Ponz, Piera, 2011). Szumy uszne somatosensoryczne mogą mieć także związek z problemami z szyjąi/lub głową (Sanchez, Rocha, 2011). Na dzień dzisiejszy pełne wyleczenie z tinnitusu nie jest możliwe (McFerran, Stockdale, Holme, Large, Baguley, 2019).

Mimo powszechności tinnitusu i jego negatywnego wpływu na funkcjonowanie części (w przybliżeniu 20\%) doświadczających go osób, tinnitus nie funkcjonuje jako odrębna jednostka kliniczna w klasyfikacji ICD-11 czy DSM-V (De Ridder i in., 2021)³. W ostatnim czasie pojawiły się próby utworzenia ,międzynarodowej interdyscyplinarnej definicji tinnitusu" (De Ridder i in., 2021), która miałaby zostać uznana przez Światową Organizację Zdrowia (WHO). Definicja ta zakłada rozróżnienie tinnitusu (tinnitus) od zespołu zaburzeń wywołanych szumami usznymi (tinnitus disorder). Zgodnie z nią, tinnitus jest świadomym zdawaniem sobie sprawy (conscious awareness) z tonalnego lub szumowego sygnału, dla którego nie ma zewnętrznego źródła akustycznego. Tinnitus może przejść w tinnitus disorder, gdy z komponentem słuchowym/sensorycznym (tinnitusem) skojarzony zostanie dystres emocjonalny, dysfunkcje poznawcze i/lub

${ }^{3}$ W ICD-11 szumy uszne wspomniane są w kontekście zaburzeń słyszenia, jako symptom niespecyficzny. W DSM-V nie pojawia się żadna wzmianka o tinnitusie (De Ridder i in., 2021). 
pobudzenie układu autonomicznego, prowadzące do funkcjonalnych zmian i funkcjonalnego upośledzenia.

\section{Fizjologiczno-behawioralny model tinnitusu}

Zwolennicy konstruowania zwierzęcych modeli tinnitusu podkreślają, że wiedza uzyskana w badaniach tego typu może być wykorzystywana do modelowania percepcji szumów usznych u ludzi na wczesnych etapach przetwarzania informacji słuchowej lub stanowić podstawy do podjęcia prób przetestowania skuteczności badanego podejścia u ludzi (Salvi, Lobarinas, Sun, 2011).

Kaltenbach (2011) wyróżnia dwa rodzaje zwierzęcych modeli tinnitusu - behawioralne i fizjologiczne. Pierwsze z nich umożliwiają określenie psychofizycznej charakterystyki szumów usznych oraz metody ich wywoływania, drugie zajmują się obserwacją zmian współtowarzyszących percepcji tinnitusu na poziomie układu nerwowego.

Paradygmaty wykorzystywane na etapie konstrukcji modeli behawioralnych opierają się przede wszystkim na zjawisku warunkowania motorycznych reakcji zwierzęcia ${ }^{4}$. Trening zwierzęcia jest jednak czasochłonny, a poza tym podejście to wymaga utworzenia grupy kontrolnej. Alternatywą do treningu zwierzęcia jest wykorzystanie występującego u niego naturalnie zjawiska akustycznego odruchu zaskoczenia (acoustic startle reflex). Zjawisko to polega na niewolicjonalnym skurczu mięśni w uchu środkowym w odpowiedzi na nagły hałas ${ }^{5}$. W modelach fizjologicznych za cel stawia się zmierzenie zmian w aktywności pojedynczych komórek nerwowych lub ich populacji

${ }^{4}$ W trakcie wymagających sesji treningowych poprzez użycie odpowiednich wzmocnień (pozytywnych lub negatywnych, polegających na administracji odpowiednio nagrody lub kary) testowane zwierzęta uczone są przejawiać odmienne zachowania w zależności od tego, czy przebywają w warunku związanym z percepcją dźwięku, czy w warunku ciszy. Percypowanie przez zwierzęta tinnitusu ma sprawić, że warunek ciszy nie będzie przez nie właściwie wykrywany.

5 Podstawą działania tego typu modeli jest założenie o możliwości wywarcia wpływu na wielkość odruchu. W badaniach wykorzystuje się szum tła (background noise), który przerwany jest „lukami” - momentami ciszy. W przypadku percypowania przez zwierzę tinnitusu luki w szumie zostają wypełnione jego dźwiękiem, a odruch ulega pomniejszeniu. Stanowi to potwierdzenie rozwinięcia szumów usznych. 
w następstwie postrzegania szumów usznych ${ }^{6}$. Największym wyzwaniem dla tych modeli jednak jest brak bezpośredniego potwierdzenia, że rejestrowane zmiany zachodzą rzeczywiście w konsekwencji zaistnienia tinnitusu.

Niezależnie od stosowanego paradygmatu, w pierwszej fazie konieczne jest wywołanie u zwierząt wrażenia zbliżonego do ludzkich szumów usznych. Według von der Behrensa (2014) osiągnąć to można przede wszystkim poprzez użycie środków farmakologicznych (salicylany, chinina) lub posłużenie się dźwiękami o wysokim natężeniu w celu wywołania urazu akustycznego (acoustic trauma) ${ }^{7}$.

W 1988 roku Jastreboff i współpracownicy stworzyli przełomowy dla badaczy szumów usznych fizjologiczno-behawioralny model tinnitusu (Jastreboff, 1990), łączący oba podejścia. Poprzez administrację salicylanu sodu wywoływali u świnek morskich percepcję szumów usznych. We wzgórku dolnym (IC) odnotowali zmiany wyładowań, które przypominały powstające w odpowiedzi na realny dźwięk wzorce aktywności. Aktywność neuronalna świnek morskich sugerowała, że zwierzęta doświadczają percepcji dźwięku (część fizjologiczna modelu).

Na drugim etapie, poprzez odwołanie się do paradygmatu warunkowanego tłumienia (Estes, Skinner, 1941), skonstruowano behawioralny paradygmat detekcji tinnitusu u zwierząt, który miał potwierdzać wystąpienie u nich szumów usznych. W tej części posłużono się dorosłymi szczurami poddanymi uprzednio deprywacji wody. W fazie warunkowania, poprzez administrację szoku elektrycznego w momentach wyłączania prezentowanego

${ }^{6} \mathrm{Z}$ tym zamiarem prowadzone są badania z wykorzystaniem narzędzi do pomiarów elektrofizjologicznych (np. mikroelektrod precyzyjnie umieszczanych w interesujących badacza komórkach nerwowych zwierzęcia poddanego anestezji) lub metod neuroobrazowania.

${ }^{7}$ Zastosowanie odpowiednio wysokich dawek salicylanów skutkuje zmianami obserwowanymi na różnych, zarówno centralnych i peryferyjnych, piętrach przetwarzania informacji słuchowej. Warto odnotować, że administracja roztworu salicylanu (stężenie $\geq 300 \mathrm{mg} / \mathrm{L}$ ) wywołuje tinnitus także u ludzi, a zażycie odpowiednio wysokiej dawki aspiryny skutkuje powstaniem wrażenia, którego charakterystyki są zbliżone do wrażenia powstającego u zwierząt (wysokość dźwięku, powolny początek jego powstania oraz powolne zanikanie wrażenia). Aby doprowadzić natomiast do powstania urazu akustycznego, zwierzę poddaje się jedno- lub dwugodzinnej eskpozycji obuusznej na „dopasowany” do gatunku dźwięk o wysokim natężeniu (np. dla szczurów jest to szum szeroki na jedną oktawę, którego częstotliwość środkowa wynosi $16 \mathrm{kHz}$, a poziom prezentacji $116 \mathrm{~dB}$ SPL) (Kaltenbach, 2011). 
szumu, wywoływano w spragnionych zwierzętach strach prowadzący do unikania picia wody w trakcie zapadającej ciszy. Szumy uszne wywoływane były na dwa sposoby - farmakologicznie lub za pomocą dźwięku. Podstawą do wyciągnięcia wniosków o rozwinięciu przez szczury tinnitusu była analiza liczby polizań przez zwierzęta podajnika wody w fazie testowej (bez administracji szoku elektrycznego). Zwierzęta, u których faza warunkowania następowała przed wywołaniem szumów usznych, wykazały się istotnie większą liczbą polizań podajnika w porównaniu do zwierząt, u których faza ta następowała później. Wywołany farmakologicznie lub za pomocą dźwięku efekt zdawał się zastępować zwierzętom prezentowany szum, co prowadziło do częstszych prób napicia i stanowiło podstawę do wyciągnięcia wniosku o zaistnieniu (detekcji przez zwierzę) szumów usznych.

Zdaniem Brozoskiego i Bauer (2016) zwierzęce modele tinnitusu, które zostały zaproponowane po pojawieniu się modelu Jastreboffa, korzystają z niego, a między sobą dzielą cechy wspólne, takie jak dążenie do wystąpienia konkretnego zachowania badanego zwierzęcia oraz wprowadzenie szumu tła, który jest dźwiękiem zestawianym z ciszą.

Modyfikowane bywają sposoby wywoływania tinnitusu (np. z zamiarem generowania tinnitusu jednousznego - Bauer, 2003), wyuczane zachowania (np. warunkowanie preferencji podajnika wody z pary urządzeń - Heffner, Koay, 2005; warunkowanie preferencji miejsca - Yang, Weiner, Zhang, Cho, Bao, 2011), rodzaj wzmacniania (negatywne, szokiem elektrycznym, np. Heffner, Harrington, 2002; Lobarinas, Sun, Cushing, Salvi, 2004, oraz pozytywne, roztworem sacharozy lub kulkami jedzenia, np. Rüttiger, Ciuffani, Zenner, Knipper, 2003; Guitton, Dudai, 2007; Yang $\mathrm{i}$ in., 2011), środowiska testowe (basen-labirynt z ukrytą platformą - Guitton i Dudai, 2007; pomieszczenia o różnym stopniu oświetlenia - Yang i in., 2011) oraz metody potwierdzenia zaistnienia szumów usznych (np. hamowanie odruchu zaskoczenia, wzbudzonego dźwiękiem, wywołanego czasową przerwą akustyczną - Turner i in., 2006).

\section{Wybrane neurofizjologiczne modele tinnitusu}

Jako przyczynę tinnitusu u ludzi często wskazuje się ubytek słuchu (m.in. Martines i in., 2010; Baracca i in., 2011; Henderson i in., 2011; Kleinjung, 2011; Møller, 2011a; Roberts, 2011; Schecklmann i in., 2012). Dużym 
utrudnieniem w zrozumieniu tego mechanizmu jest obserwacja, że nie każda niesłysząca lub niedosłysząca osoba rozwija szumy uszne. Starając się uzyskać odpowiedzi dotyczące złożonej natury tinnitusu, badacze podnieśli kwestię peryferyjnych i centralnych mechanizmów ich generowania. Swoistą trudność sprawiała jednak pewna niespójność w definicji kluczowego w tej kwestii pojęcia „generowanie”. Część badaczy ujmowała ją w kategorie pierwszych zmian, które mogły zostać zaobserwowane w układzie słuchowym, a które niekoniecznie prowadziły do postrzegania szumów usznych. Inni definiowali ją jako aktywność powstającą na wyższych etapach przetwarzania informacji słuchowej, prowadzącą do świadomej percepcji szumów (Salvi, Lobarinas, Sun, 2011). Najszersze grono zwolenników zyskała jednak hipoteza będąca połączeniem obu podejść, wskazująca na dualną naturę tinnitusu (peryferyjno-centralną)

\subsection{Model neuronalnej synchroniczności}

Przedstawiony w 2004 roku model neuronalnej synchroniczności (neural synchrony model of tinnitus - Eggermont, Roberts, 2004) zakłada zaistnienie hiperaktywności w układzie słuchowym. Dysfunkcja części peryferyjnych układu słuchowego skutkuje odcięciem części centralnej układu od dopływu sygnału (informacja słuchowa nie jest prawidłowo lub w ogóle przekazywana) i prowadzi do anormalnej synchronizacji neuronów. W konsekwencji dochodzi do obniżenia procesów hamowania w danym obszarze i zwiększonej częstości spontanicznych wyładowań neuronów.

W badaniu przeprowadzonym na kotach (Eggermont, Roberts, 2004) badacze zaobserwowali, że: 1) ekspozycja na zbyt intensywny dźwięk doprowadza do zmian w korowej organizacji tonotopowej (organizacji obszarów związanych z dekodowaniem częstotliwości dźwięku), 2) komórki nerwowe dostrojone do odkodowywania dźwięków o częstotliwości związanej z dźwiękiem wywołującym uszkodzenie słuchu pozostają nieaktywne w odpowiedzi na stymulację, 3) obserwowana w nich jest zwiększona

8 Interesującą syntezę przedstawiają m.in. Salvi, Lobarinas i Sun (2011), wskazując na prawdopodobieństwo istnienia różnic w percepcji tinntiusu pomiędzy jego wczesnym i późnym etapem w konsekwencji ich odmiennych charakterystyk - w pierwszej fazie powstawania szumów usznych możemy mieć do czynienia ze zmianami peryferyjnymi, w fazie późniejszej natomiast z centralnymi zmianami związanymi ze zjawiskiem plastyczności. 
spontaniczna aktywność i synchronizacja oraz 4) w komórkach z nimi sąsiadujących można odnotować pobudzenie.

Badacze zauważają, że komórki nerwowe w przypadku braku (lub redukcji) informacji wejściowej dostrajają się do częstotliwości z pogranicza ubytku słuchu, co w rezultacie manifestuje się jej poszerzoną reprezentacją (więcej komórek nerwowych odbiera tę samą częstotliwość). Wcześniejsze badania sugerują, że nadreprezentacja tych częstotliwości skutkuje lepszą detekcją i dyskryminacją odpowiadających jej dźwięków - osoby z tinnitusem wykazują się zwiększoną efektywnością w zadaniach dla częstotliwości przyległych do ubytku słuchu (Wiegrebe, Kössl, Schmidt, 1996). Sama nadreprezentacja nie jest jednak wystarczająca do spostrzeżenia szumów usznych. Ich percepcja jest możliwa dopiero po odpowiednim odebraniu sygnałów docierających z obszarów nadreprezentowanych przez dalsze ośrodki słuchowe.

Rozpatrując oba zjawiska - zwiększoną spontaniczną aktywność oraz synchronizację neuronalną, jako bardziej prawdopodobny korelat tinntiusu - badacze wskazują drugie z nich - synchronizację neuronalną, ponieważ występuje ona w obszarze zreorganizowanym. Zmiany (wzrost) spontanicznych wyładowań neuronów mogą zostać zaobserwowane również poza nim. Zjawiska te mogą być jednak połączone - zwiększona aktywność komórek nerwowych może sprzyjać rozwojowi synchronizacji. W warunkach optymalnych, w sprawnie działającym układzie słuchowym, synchroniczność jest ograniczana do pobudzanych obszarów. Przy obniżeniu hamowania obserwowanego w ubytku słuchu zsynchronizowanie wyładowań może się poszerzać, skutkując percepcją nieistniejącego dźwięku (Eggermont, Roberts, 2004; Roberts, 2011).

\subsection{Model wzmocnienia centralnego}

Do zwolenników modeli opartych na hiperaktywności należą także Noreña i Faley (2013). Uważają oni, że tinnitus jest konsekwencją zmian spowodowanych deprywacją słuchową lub przewodzeniowym uszkodzeniem słuchu, niezależnie od uwidocznienia ubytku słuchu na audiogramie pacjenta z szumami usznymi ${ }^{9}$.

9 Mimo prawidłowych progów słyszenia odnotowanych w audiometrii tonalnej, u pacjenta można stwierdzić ubytek słuchu poprzez użycie innych metod testowych, por. Weisz i in., 2006; Etchelecou, Coulet, Derkenne, Tomasi, Noreña, 2011; Schaette, McAlpine, 2011. 
Uszkodzenie na poziomie ślimaka wejść peryferyjnych powoduje hiperaktywność, będącą konsekwencją działania procesów homeostatycznych, których zadaniem jest m.in. utrzymanie konkretnej średniej aktywności komórek nerwowych w przypadku deprywacji sensorycznej. Odcięcie od napływających informacji prowadzi do zwiększonej spontanicznej aktywności oraz synchroniczności na różnych poziomach przetwarzania informacji słuchowej w centralnym układzie słuchowym (Noreña, 2011). Czasowa koherencja aktywności neuronów presynaptycznych (sąsiadujących lub odległych) zwiększa prawdopodobieństwo pobudzenia wspólnego obszaru postsynaptycznego. Biorąc pod uwagę nadreprezentację częstotliwości przyległych do ubytku słuchu oraz obniżenie hamowania bocznego (Wiegrebe, Kössl, Schmidt, 1996; Eggermont, Roberts, 2004), założyć można, że obszary wcześniej reprezentujące ubytek słuchu oraz do niego przyległe, będą otrzymywać tę samą informację wejściową. Synchroniczność pomiędzy nimi wzrośnie, a kolejne ośrodki przetwarzania informacji będą aktywowane z większą łatwością, co może owocować percepcją tinnitusu. Szumy uszne mogą być konsekwencją „dopasowywania” się ośrodków centralnych do zmian w peryferyjnej części układu słuchowego, np. poprzez zwiększenie liczby spontanicznych wyładowań neuronów centralnych.

Opisywane zmiany mogą brać swój początek w zjawisku tzw. wzmocnienia centralnego (central gain), służącym dopasowaniu czułości słuchowych komórek nerwowych (w części centralnej układu słuchowego) do zmian w poziomie napływających dźwięków (Cai, Ma, Young, 2009). Zmiany we wzmocnieniu centralnym odpowiadają za utrzymanie odpowiedniej średniej aktywności komórek. Wyjaśnienie to jest sugerowane również przez niektóre modele obliczeniowe (Schaette, Kempter, 2006).

\subsection{Model tłumienia tinnitusu oparty na metabotropowych receptorach glutaminianu}

Galazyuk i współpracownicy prezentują inne podejście do spontanicznej aktywności, testując przypuszczenie, że jej stłumienie może doprowadzić do zniesienia lub redukcji fantomowego dźwięku (Galazyuk i in., 2019). Za supresję hiperaktywności odpowiadają metabotropowe receptory glutaminianu (mGluRs). Proponowane podejście do szumów usznych (być może uznane za terapeutyczne w przyszłości) oparte jest na administracji specyficznego agonisty mGluR grupy II LY354740. Badania zespołu wykazały, że ogranicza on 
spontaniczną aktywność neuronalną w IC u myszy z tinnitusem, prowadząc do zniesienia behawioralnych oznak tinnitusu i nie wpływając przy tym znacząco na poziom aktywności wywołanej dźwiękiem.

Pewna spontaniczna aktywność komórek nerwowych jest standardowo obserwowana w różnych modalnościach w sytuacji braku bodźca i określana bywa mianem ,wewnętrznego szumu”. Szum ten nie wpływa na zdolność do przetwarzania bodźców czy doświadczania ciszy. W przypadku jednak braku informacji wejściowej (występującym np. przy uszkodzenia ślimaka) w systemie centralnym dochodzi do podniesienia spontanicznej aktywności neuronów. Została ona zaobserwowana m.in. w słuchowej części pnia mózgu, wzgórzu, korze i ciemieniowo-potylicznych obszarach kory skojarzeniowej. Badacze nie negują jednak możliwości istnienia innych potencjalnych korelatów tinnitusu (np. wspomnianą synchroniczność neuronalną). Mogą one jednak zależeć od zwiększonej spontanicznej aktywności komórek, być przez nią wywołane lub jej towarzyszyć ${ }^{10}$.

\section{Wybrane modele zespołu zaburzeń wywołanych szumami usznymi}

O ile mechanizmy powstawania percepcji tinnitusu znajdują się już od dziesiątek lat w centrum zainteresowania naukowców, o tyle czynniki prowadzące do towarzyszącego jej cierpienia (ZZWSU) pozostają niezrozumiane. Modele, które starają się zaadresować tę kwestię, uwzględniają aspekty psychologiczne i poznawcze.

\subsection{Neurofizjologiczny model szumów usznych}

Jeden z najbardziej wpływowych modeli tinnitusu - Neurofizjologiczny Model Szumów Usznych (Neuropshysiological Model of Tinnitus - Jastreboff, 1990) zakłada, że fantomowy dźwięk powstaje w konsekwencji zmian

${ }^{10}$ Za tym, że neuronalna synchroniczność jest w dużej mierze zależna od hiperaktywności, przemawiać mogą obserwacje dokonane przez Sedleya i współpracowników (2015) w trakcie procedury tzw. live brain mapping. Przeprowadzone przez nich badania wykazały, że oscylacje fal mózgowych ulegają silnym zmianom w konsekwencji wywołania zjawiska tzw. hamowania szczątkowego (residual inhibition - RI) (Feldmann, 1971; Galazyuk i in., 2019; Sedley i in., 2015). 
zachodzących w aktywności komórek nerwowych na różnych piętrach przetwarzania informacji słuchowej. Zmiany te interpretowane są przez układ słuchowy jako realnie istniejący dźwięk.

Samo generowanie tinnitusu nie jest jednak wystarczające do jego percepcji - tinnitus musi zostać wcześniej: 1) wykryty, 2) rozpoznany oraz 3) uznany za istotny. Zdaniem badacza, w pierwszej kolejności w obszarach podkorowych przekroczony musi zostać próg detekcji, względnie słabego sygnału w celu odróżnienia go od szumu tła. Następnie wzorzec aktywności towarzyszący tinnitusowi musi zostać rozpoznany. Do percepcji szumów usznych dochodzi w ostatniej fazie, wraz z psychologiczną ewaluacją dostrzeżonego wzorca aktywności i jego klasyfikacją. Interpretacja wzorca odgrywa kluczową rolę w tworzeniu późniejszej reakcji na niego i wpływa na próg detekcji sygnału, a co za tym idzie, jego rozpoznanie. Utrwalany lub wzmacniany wzorzec może zostać zakwalifikowany jako istotny, co spowoduje trudności z osłabieniem jego percepcji. Etap ten prawdopodobnie zachodzi z udziałem kory skojarzeniowej i może być związany z przeżywaniem silnych emocji. Poprzez skojarzenie sygnału z informacją emocjonalną, kierowane na niego są większe zasoby uwagi i zyskuje on większe znaczenie. Brak przypisania reakcji emocjonalnej do sygnału może skutkować zignorowaniem fantomowego dźwięku, natomiast negatywna reakcja na szumy uszne wzmacnia percepcję tinnitusu. Powtarzająca się aktywacja połączeń między układem limbicznym i autonomicznym układem nerwowym może doprowadzić do ich wzmocnienia i przejścia tinnitusu w stan chroniczny (i w ZZWSU). Aktywacja tych układów może przebiegać z zaangażowaniem tzw. pętli wyższej i niższej. Pierwsza z nich związana jest ze świadomymi wyższymi procesami poznawczymi, druga obejmuje ośrodki, które przetwarzają sygnał poza udziałem świadomości (Jastreboff, 1990) ${ }^{11}$.

\subsection{Integracyjny model słuchowej percepcji fantomowej}

W integracyjnym modelu słuchowej percepcji fantomowej (an integrative model of auditory phantom perception - De Ridder i in., 2014) wskazane

11 Opisywany model stał się podstawą terapii Tinnitus Retraining Teraphy (TRT), która poprzez zwiększenie wiedzy pacjenta nt. szumów usznych oraz użycie generatorów dźwięku zmierza do eliminacji tinnitusu. Cel ten osiągany jest odpowiednio przez habituację negatywnej reakcji na tinnitus, a następnie habituację jego percepcji, tak, że staje się on ignorowany (Jastreboff, 1990, 2007). 
zostają obszary, których jednoczesna aktywacja jest konieczna do zaistnienia percepcji szumów usznych. Rdzeniem fantomowego dźwięku jest sieć, która związana jest z głośnością, lateralizacją, dystresem oraz typem (ton vs. szum) tinnitusu. Szumy uszne są własnością, która wyłania się w następstwie częściowego nałożenia na siebie szeregu równoległych sieci neuronalnych podlegających dynamicznym zmianom (w tym sieci będącej rdzeniem tinnitusu). Każda z tych sieci charakteryzuje się własnym wzorcem połączeń i aktywnością, a interakcja między nimi zachodzi poprzez centra komunikacyjne ( $h u b s)$. Centra te to obszary mózgu, które przynależą do różnych sieci, jednak udzielają się w nich z różną, przypisaną do danej sieci, częstotliwością.

Według De Riddera szumy uszne mogą wiązać się z aktywnością fal gamma w korze słuchowej oraz zagnieżdżoną w niej aktywnością theta. Pozbawienie informacji wejściowej skutkuje synchroniczną aktywnością komórek nerwowych (w zakresie fal gamma) należących do danej kory sensorycznej. Aktywność ta zostaje dostrzeżona jednak dopiero wtedy, gdy dochodzi do połączenia jej z aktywacją innych sieci, takich jak sieć istotności (odpowiada za proces docierana do świadomości ważnych bodźców) czy sieć świadomości (autopercepcji). Tinnitus, poprzez mechanizmy uczenia się, zostaje skojarzony z nieprzyjemnym odczuciem (dystresem), a w utrzymanie fantomowej percepcji zostaje także zaangażowana pamięć, wpływająca na utrzymanie świadomości fantomowego dźwięku i dystresu (De Ridder i in., 2011; 2014).

W omawiany model integracyjny włączony zostaje także mechanizm anulowania szumu (noise cancelation) zaproponowany przez Rauscheckera (Rauschecker, Leaver, Mühlau, 2010). Mechanizm ten poprzez jądro półleżące (NAc) oraz sieci paralimbiczne odpowiadające mu w brzuszno-przyśrodkowej korze przedczołowej (vmPFC) umożliwia habituację do nieprzyjemnych dźwięków. Gdy mechanizm działa poprawnie, sygnał tinnitusu jest „odfiltrowywany” i nie trafia do kory słuchowej oraz świadomego spostrzeżenia. Nieprawidłowości w działaniu systemu NAc mogą doprowadzić do sytuacji, w której zniesienie sygnału może nie być możliwe, a szumy uszne są percypowane. 


\subsection{Poznawczo-behawioralny model percepcji tinnitusu}

Najbardziej psychologiczny z przedstawionych, poznawczo-behawioralny model percepcji tinnitusu (McKenna, Handscomb, Hoare, Hall, 2014) oparty został na założeniu, że procesy poznawcze pośredniczą w zachowaniu i mogą na nie wpływać. Podobnie jak w przypadku chronicznego bólu, bezsenności czy niepokoju, percepcja tinnitusu może wiązać się z odczuwaniem nadmiernego niepokoju powstałego na skutek błędnej interpretacji symptomów czy też informacji na temat tego zjawiska, doprowadzających do wniosku, że osoba cierpi na poważną chorobę. Model zakłada, że niezależnie od przyczyny powstania tinnitusu, negatywne myśli rozpoczynają proces jego percepcji, ponieważ zachodzące w pacjencie procesy poznawczo-behawioralne prowadzą do powstania dystresu. W pierwszej kolejności aktywność neuronalna współtowarzysząca szumom usznym zostaje wykryta, co związane jest z pojawieniem się negatywnych myśli (automatycznych). W następstwie odczuwane zostaje pobudzenie i dystres, wpływające na procesy monitorowania, uwagę selektywną i rozwój zachowań bezpiecznych (strategie radzenia sobie z niepokojem lub strachem). Zarówno podwyższona uwaga selektywna, jak i procesy monitorowania ułatwiają wykrycie sygnału tinnitusu, a zachowania bezpieczne na ogół nie okazują się adaptacyjne i prowadzą do jego zwrotnej detekcji i zaistnienia negatywnych myśli, które - co więcej - mogą zostać spotęgowane niewłaściwymi autoprzekonaniami czy też przekonaniami o świecie zewnętrznym ${ }^{12}$.

\section{Podsumowanie. Tinnitus a słyszenie przedmiotów}

Fantomowa percepcja to świadomość perceptu przy nieobecności zewnętrznego bodźca (De Ridder i in., 2011). W kontekście modalności słuchowej za jej przykład możemy uznać percepcję tinnitusu (szumów usznych). Przedstawiony w niniejszej pracy przegląd wybranych modeli generowania

12 Model ten znajduje zastosowanie w terapii poznawczo-behawioralnej, w której związek między zdarzeniem a reakcją emocjonalną nie jest bezpośredni, powstaje dopiero w momencie poczynienia interpretacji. Negatywny stan emocjonalny powstaje przez pojawienie się negatywnych myśli na temat słyszanego sygnału. Sytuacja staje się problematyczna, gdy negatywnych myśli jest za dużo, a zdarzenia interpretowane jako gorsze niż są w rzeczywistości. 
i percepcji tego zjawiska posłużył zaprezentowaniu propozycji klasyfikacji istniejących modeli do dwóch wyłaniających się grup - modeli opisujących mechanizmy powstawania tinnitusu (tinnitus) oraz modeli generowania dokuczliwych szumów usznych (ZZWSU). W powstawanie tinnitusu zaangażowane są zmiany zachodzące na poziomie neuronalnym (z dużym prawdopodobieństwem powstające w konsekwencji deaferentacji), które po przekroczeniu progu detekcji skutkują świadomą percepcją szumów usznych (tinnitus). Wyższe funkcje poznawcze, a także emocje, biorą udział w generowaniu i podtrzymaniu fantomowej percepcji, prowadząc do wystąpienia ZZWSU. O ile jednak mechanizmami generowania tinnitusu badacze interesują się od lat (najbardziej prawdopodobnym kandydatem zdaje się być podwyższona spontaniczna aktywność neuronów lub też powiązana z nią/ będąca jej następstwem synchroniczność neuronów), czynniki prowadzące do jego przejścia w zespół zaburzeń wywołanych szumami usznymi wymagają głębszego zbadania. Istniejące modele podkreślające rolę procesów poznawczych i psychologicznych, mimo iż przybliżają nas do tego celu, nie wskazują jednoznacznego kryterium rozwinięcia ZZWSU - czy same negatywne myśli o tinnitusie wystarczą? Czy konieczne jest posiadanie konkretnego typu osobowości? Ile czasu należy poświęcić myślom o szumach usznych, żeby z formy niedokuczliwej przerodziły się w uciążliwą? Jakie warunki muszą zostać spełnione, żeby osoba, która akceptuje szumy uszne, zaczęła cierpieć z ich powodu? W przyszłych badaniach należałoby podjąć te i podobne kwestie.

Kolejnym krokiem dla badaczy może być skonstruowanie modelu będącego np. rozwinięciem integracyjnego modelu słuchowej percepcji fantomowej (De Ridder i in., 2014), na podstawie którego będzie można wskazać przyczyny występowania nieprawidłowości (np. przyczyny nakładania się na siebie aktywności różnych sieci neuronalnych) różnicujących osoby z dokuczliwymi szumami usznymi od osób, dla których nie stanowią one poważniejszego problemu (tinnitus).

W badanie mechanizmów leżących u powstawania tinnitusu, podtrzymywania jego percepcji, a także w próby znalezienia skutecznego leku, zaangażowani są przedstawiciele różnych dyscyplin naukowych. Prowadzone badania czerpią z podejścia audiologicznego (np. Møller, 2011a), psychologicznego (m.in. Jastreboff, Hazell, 2004; McKenna i in., 2014), metod obliczeniowych (np. Schaette, Kempter, 2006), a także korzystają 
z neuronaukowych metod badawczych (m.in. Eggermont, Robberts, 2004; De Ridder i in., 2014).

Tinnitus (pojmowany tu jako oba - tinnitus oraz zespół zaburzeń wywołanych szumami usznymi) jest zjawiskiem złożonym, którego zrozumienie wymaga interdyscyplinarnego podejścia typowego dla nauki, jaką jest kognitywistyka. Szumy uszne mogą zainteresować kognitywistów jednak nie tylko z racji interdyscyplinarnego charakteru badań poświęconych tinntusowi. Ogólny obraz, który wyłania się z tej pracy, być może przyniesie istotne konsekwencje dla filozoficznych debat na temat natury obiektów słuchowych.

Tinnitus może być traktowany jako obiekt słuchowy zgodnie $\mathrm{z}$ teorią niezbędnych atrybutów (Kubovy, Van Valkenburg, 2001). Zaprezentowany zostaje w niej pogląd, że czas i wysokość są niezbędnymi atrybutami obiektów słuchowych, tak jak w modalności wzrokowej funkcję tę pełnią przestrzeń i czas. Według Griffithsa i Warrena (2004) obiekt słuchowy może być definiowany jako akustyczne doświadczenie, które tworzy dwuwymiarowy „obraz”, na który składa się wymiar czasu i częstotliwości. Jeśli atrybuty niezbędne potraktujemy jako wystarczające, tinnitus, mogący zostać przez pacjenta dopasowany do dźwięku zewnętrznego (porównany z dźwiękiem) o określonej częstotliwości, którego percepcja przebiega w czasie, spełnia konieczne warunki bycia obiektem słuchowym.

Szumy uszne, mimo że nie mają swojego zewnętrznego źródła, spontanicznie traktowane są przez osobę doświadczającą jako reprezentacja czegoś zewnętrznego (Casati, Dokic, Di Bona, 2020), czyli „słyszenie przedmiotu” w ujęciu Klawitera (1999). Zdaje się to być całkowicie uzasadnione, jeśli idąc za Maclachlan (1989) uznamy, że słuchowe doświadczenie przedmiotów czy zdarzeń nie jest słyszeniem zmian w ciśnieniu powietrza, ale wewnętrznymi i prywatnymi wrażeniami (senesations) powstałymi na podstawie danych słuchowych (O’Callaghan, 2021). Danymi słuchowymi w przypadku tinnitusu są zmiany na poziomie neuronalnym (podwyższona spontaniczna aktywność neuronów, ich synchronizacja) prowadzące do jego zaistnienia i skutkujące percepcją dźwięku po przekroczeniu progu ich detekcji.

W 1996 roku Ramachandran i Rogers-Ramachandran zaproponowali pacjentom z fantomowymi kończynami ,pudełko wirtualnej rzeczywistości” (virtual reality box). Zostało ono skonstruowane w taki sposób, że osoba badana, umieszczając w nim zdrową rękę, spoglądała na jej odbicie w lustrze. Odpowiednie usadowienie pacjenta przyczyniało się do stworzenia wrażenia, 
że ręka w odbiciu jest ręką fantomową. W procedurze poprzez manipulacje zdrową ręką pacjenci byli w stanie pozbyć się fantomowego bólu (np. przez otwarcie boleśnie zaciśniętej fantomowej pięści) (Ramachandran i Rogers-Ramachandran, 1996). Do dzisiaj badacze zainteresowani zjawiskiem tinnitusu poszukują ,,pudełka wirtualnej rzeczywistości” dostosowanego do modalności słuchowej. Być może koncentracja wysiłku na badaniach mogących rzucić światło na zespół zaburzeń wywołanych szumami usznymi doprowadzi do znalezienia skutecznego leku.

\section{Bibliografia}

Baracca, G., Del Bo, L., Ambrosetti, U. (2011). Tinnitus and Hearing Loss. W: A.R. Møller, B. Langguth, D. De Ridder, T. Kleinjung (red.), Textbook of Tinnitus (s. 285-291). New York, NY: Springer.

Bartnik, G., Stępień, A., Raj-Koziak, D., Fabijańska, A., Niedziałek, I., Skarżyński, H. (2012). Troublesome Tinnitus in Children: Epidemiology, Audiological Profile, and Preliminary Results of Treatment. International Journal of Pediatrics, 2012 (6), 945356. DOI: 10.1155/2012/945356.

Bauer, C.A. (2003). Animal Models of Tinnitus. Otolaryngologic Clinics of North America, 36 (2), 267-285. DOI: 10.1016/s0030-6665(02)00171-8.

Behrens, W. von der (2014). Animal Models of Subjective Tinnitus. Neural Plasticity, 13. DOI: $10.1155 / 2014 / 741452$.

Brozoski, Th.J., Bauer, C.A. (2016). Animal Models of Tinnitus. Special Issue: Annual Reviews, 338, 88-97. DOI: 10.1016/j.heares.2015.10.011.

Cai, S., Ma, W.-L.D., Young, E.D. (2009). Encoding Intensity in Ventral Cochlear Nucleus Following Acoustic Trauma: Implications for Loudness Recruitment. Journal of the Association for Research in Otolaryngology, 10 (1), 5-22. DOI: 10.1007/s10162-008-0142-y.

Casati, R., Dokic, J., Di Bona, E. (2020). Sounds. W: E.N. Zalta (red.), The Stanford Encyclopedia of Philosophy. Pobrano z: https://plato.stanford.edu/archives/ win2020/entries/sounds/ (15.04.2021).

Chung, J.H., Byun, H., Lee, S.H., Park, C.W., Jang, E.Y. (2017). Temperament and Character Tin Patients with Tinnitus: A Prospective Case Series with Comparisons. Clinical Otolaryngology. DOI: 10.1111/coa.12805.

Crönlein, T., Langguth, B., Pregler, M., Kreuzer, P.M., Wetter, T.C., Schecklmann, M. (2016). Insomnia in Patients with Chronic Tinnitus: Cognitive 
and Emotional Distress as Moderator Variables. Journal of Psychosomatic Research, 83, 65-68. DOI: 10.1016/j.jpsychores.2016.03.001

De Ridder, D., Elgoyhen, A.B., Romo, R., Langguth, B. (2011). Phantom Percepts: Tinnitus and Pain as Persisting Aversive Memory Networks. Proceedings of the National Academy of Sciences, 108 (20), 8075. DOI: 10.1073/ pnas.1018466108.

De Ridder, D., Vanneste, S., Weisz, N., Londero, A., Schlee, W., Elgoyhen, A.B., Langguth, B. (2014). An Integrative Model of Auditory Phantom Perception: Tinnitus as a Unified Percept of Interacting Separable Subnetworks. Neuroscience and Biobehavioral Reviews, 44, 16-32. DOI: 10.1016/j.neubiorev.2013.03.021.

De Ridder, D., Schlee, W., Vanneste, S., Londero, A., Weisz, N., Kleinjung, T., i in. (2021). Tinnitus and Tinnitus Disorder: Theoretical and Operational Definitions (An International Multidisciplinary Proposal). Progress in Brain Research, 260, 1-25. DOI: 10.1016/bs.pbr.2020.12.002.

Eggermont, J.J., Roberts, L.E. (2004). The Neuroscience of Tinnitus. Trends in Neurosciences, 27 (11), 676-682. DOI: 10.1016/j.tins.2004.08.010.

Estes, W.K., Skinner, B.F. (1941). Some Quantitative Properties of Anxiety. Journal of Experimental Psychology, 29 (5), 390-400. DOI: 10.1037/h0062283.

Etchelecou, M.-C., Coulet, O., Derkenne, R., Tomasi, M., Noreña, A.J. (2011). Temporary off-Frequency Listening after Noise Trauma. Hearing Research, 282 (1-2), 81-91. DOI: 10.1016/j.heares.2011.09.006.

Feldmann, H. (1971). Homolateral and Contralateral Masking of Tinnitus by Noisebands and by Pure Tones. Audiology: Official Organ of the International Society of Audiology, 10 (3), 138-144. DOI: 10.3109/00206097109072551.

Folmer, R.L., Theodoroff, S.M., Casiana, L., Shi, Y., Griest, S., Vachhani, J. (2015). Repetitive Transcranial Magnetic Stimulation Treatment for Chronic Tinnitus: A Randomized Clinical Trial. JAMA Otolaryngology - Head \& Neck Surgery, 141, 716-722. DOI: 10.1001/jamaoto.2015.1219.

Galazyuk, A.V., Longenecker, R.J., Voytenko, S.V., Kristaponyte, I., Nelson, G.L. (2019). Residual Inhibition: From the Putative Mechanisms to Potential Tinnitus Treatment. Hearing Research, 375, 1-13. DOI: 10.1016/j. heares.2019.01.022.

Griffiths, T.D., Warren, J.D. (2004). What Is an Auditory Object? Nature Reviews Neuroscience, 5, 887-892. DOI: 10.1038/nrn1538. 
Guitton, M.J., Dudai, Y. (2007). Blockade of Cochlear NMDA Receptors Prevents Long-Term Tinnitus during a Brief Consolidation Window after Acoustic Trauma. Neural Plasticity, 80904. DOI: 10.1155/2007/80904.

Hauptmann, Ch., Ströbel, A., Williams, M., Patel, N., Wurzer, H., Stackelberg, T. von, Brinkmann, U., Langguth, B., Tass, P.A. (2015). Acoustic Coordinated Reset Neuromodulation in a Real Life Patient Population with Chronic Tonal Tinnitus. BioMed Research International, 8. DOI: 10.1155/2015/569052.

Heffner, H.E., Harrington, I.A. (2002). Tinnitus in Hamsters Following Exposure to Intense Sound. Special Issue on the 38th Workshop on Inner Ear Biology, and Regular Research Papers 170 (1-2), 83-95. DOI: 10.1016/S03785955(02)00343-X.

Heffner, H.E., Koay, G. (2005). Tinnitus and Hearing Loss in Hamsters (Mesocricetus auratus) Exposed to Loud Sound. Behavioral Neuroscience, 119 (3), 734-742. DOI: $10.1037 / 0735-7044.119 .3 .734$.

Henderson, D., Bielefeld, E.C., Lobarinas, E., Tanaka, Ch. (2011). Noise-Induced Hearing Loss: Implication for Tinnitus. W: A.R. Møller, B. Langguth, D. de Ridder, T. Kleinjung (red.), Textbook of Tinnitus (s. 301-309). New York, NY: Springer New York.

Jastreboff, P.J. (1990). Phantom Auditory Perception (Tinnitus): Mechanisms of Generation and Perception. Neuroscience Research, 8(4): 221-254. DOI: 10.1016/01680102(90)90031-9.

Jastreboff, P J. (2007). Tinnitus Retraining Therapy. Progress in Brain Research, 166, 415-423. DOI: 10.1016/S0079-6123(07)66040-3.

Jastreboff, P.J., Hazell, J.W. (1993). A Neurophysiological Approach to Tinnitus: Clinical Implications. British Journal of Audiology, 27 (1), 7-17. DOI: $10.3109 / 03005369309077884$

Jastreboff, P.J., Hazell, J.W. (2004). Tinnitus Retraining Therapy: Implementing the Neurophysiological Model. Cambridge: Cambridge University Press.

Kaltenbach, J.A. (2011). Tinnitus: Models and Mechanisms. Hearing Research, 276(1-2), 52-60. DOI: 10.1016/j.heares.2010.12.003.

Kehrle, H.M., Sampaio, A.L., Granjeiro, R.C., Oliveira, T.S., Oliveira, C.A. (2016). Tinnitus Annoyance in Normal-Hearing Individuals Correlation with Depression and Anxiety. The Annals of Otology, Rhinology, and Laryngology, 125, 185-194. DOI: $10.1177 / 0003489415606445$.

Klawiter, A. (1999). O słyszeniu przedmiotów. W: A. Klawiter, L. Nowak, P. Przybysz (red.), Umysł a rzeczywistość (s. 327-339). Poznań: Zysk i S-ka. 
Kleinjung, T. (2011). Conductive and Cochlear Hearing Loss. W: A.R. Møller, B. Langguth, D. de Ridder, T. Kleinjung (red.), Textbook of Tinnitus (s. 279-284). New York, NY: Springer New York.

Kubovy, M., Van Valkenburg, D. (2001). Auditory and Visual Objects. Cognition, 80, 97-126. DOI: 10.1016/s0010-0277(00)00155-4.

Láinez, M.J.A., Ponz, A., Piera, A. (2011). Causes of Tinnitus: Cerebrovascular Diseases. W: A.R. Møller, B. Langguth, D. de Ridder, T. Kleinjung (red.), Textbook of Tinnitus (s. 337-342). New York, NY: Springer New York.

Langguth, B., Landgrebe, M., Kleinjung, T., Sand, G.Ph., Hajak, G. (2011). Tinnitus and Depression. The World Journal of Biological Psychiatry, 12 (7), 489-500. DOI: 10.3109/15622975.2011.575178.

Lobarinas, E., Sun, W., Cushing, R., Salvi, R. (2004). A Novel Behavioral Paradigm for Assessing Tinnitus Using Schedule-induced Polydipsia Avoidance Conditioning (SIP-AC). Hearing Research, 190 (1-2), 109-114. DOI: 10.1016/S03785955(04)00019-X.

Maclachlan, D.L.C. (1989). Philosophy of Perception. Englewood Cliffs, NJ: Prentice Hall.

Martines, F., Bentivegna, D., Martines, E., Sciacca, V., Martinciglio, G. (2010). Characteristics of Tinnitus with or without Hearing Loss: Clinical Observations in Sicilian Tinnitus Patients. Auris Nasus Larynx, 37 (6), 685-693. DOI: 10.1016/j. anl.2010.03.008.

May, J., Ramachandran, V., Cacace, A.T. (2011). Tinnitus and Vestibular Schwannoma: Overview and Clinical Correlations. W: A.R. Møller, B. Langguth, D. de Ridder, T. Kleinjung (red.), Textbook of Tinnitus (s. 317-325). New York, NY: Springer New York.

McFerran, D.J., Stockdale, D., Holme, R., Large, C.H., Baguley, D.M. (2019). Why Is There No Cure for Tinnitus? Frontiers in Neuroscience, 13, 802. https:// DOI.org/10.3389/fnins.2019.00802.

McKenna, L., Handscomb, L., Hoare, D.J., Hall, D.A. (2014). A Scientific Cognitive-Behavioral Model of Tinnitus: Novel Conceptualizations of Tinnitus Distress. Frontiers in Neurology, 5, 196. DOI: 10.3389/fneur.2014.00196.

Møller, A.R. (2011a). Cochlear and Non-cochlear Age-Related Hearing Loss and Tinnitus. W: A.R. Møller, B. Langguth, D. de Ridder, T. Kleinjung (red.), Textbook of Tinnitus (s. 293-300). New York, NY. 
Møller, A.R. (2011b). Misophonia, Phonophobia, and "Exploding Head" Syndrome. W: A.R. Møller, B. Langguth, D. de Ridder, T. Kleinjung (red.), Textbook of Tinnitus (s. 25-27). New York, NY: Springer New York.

Noreña, A.J. (2011). An Integrative Model of Tinnitus Based on a Central Gain Controlling Neural Sensitivity. Neuroscience \& Biobehavioral Reviews, 35 (5): 1089-1109. DOI: 10.1016/j.neubiorev.2010.11.003.

Noreña, A.J., Farley, B.J. (2013). Tinnitus-Related Neural Activity: Theories of Generation, Propagation, and Centralization. Neuroscience of Tinnitus, 295, 161-171. DOI: 10.1016/j.heares.2012.09.010.

O'Callaghan, C. (2021). Auditory Perception. W: E.N. Zalta (red.), The Stanford Encyclopedia of Philosophy. Pobrano z: https://plato.stanford.edu/archives/ fall2021/entries/perception-auditory/ (15.04.2021).

Pantev, Ch., Okamoto, H., Teismann, H. (2012). Music-Induced Cortical Plasticity and Lateral Inhibition in the Human Auditory Cortex as Foundations for Tonal Tinnitus Treatment. Frontiers in Systems Neuroscience, 6, 50. DOI: 10.3389/ fnsys.2012.00050.

Piotrowska, A., Raj-Koziak, D., Lorens, A., Skarżyński, H. (2015). Tinnitus Reported by Children Aged 7 and 12 Years. International Journal of Pediatric Otorhinolaryngology, 79 (8), 1346-1350. DOI: 10.1016/j.ijporl.2015.06.008.

Raj-Koziak, D., Bartnik, G., Fabijańska, A., Borawska, B., Skarżyński, H., Rogowski, M., Kochanek, K. (2003). Tinnitus as a Symptom of Acoustic Neuroma. Oto-Rhino-Laryngology. Proceedings of the XVII World Congress of the International Federation of Oto-Rhino-Laryngological Societies (IFOS), 1240, 313-315. DOI: 10.1016/S0531-5131(03)00720-9.

Ramachandran, V., Rogers-Ramachandran, D. (1996). Synaesthesia in Phantom Limbs Induced with Mirrors. Proceedings of the Royal Society B: Biological Sciences, 263 (1369), 377-386. DOI: 10.1098/rspb.1996.0058. PMID: 8637922 .

Rauschecker, J.P., Leaver, A.M., Mühlau, M. (2010). Tuning out the Noise: Limbic-Auditory Interactions in Tinnitus. Neuron, 66 (6), 819-826. DOI: 10.1016/j. neuron.2010.04.032.

Roberts, L.E. (2011). Neural Synchrony and Neural Plasticity in Tinnitus. W: A.R. Møller, B. Langguth, D. De Ridder, T. Kleinjung (red.), Textbook of Tinnitus (s. 103-112). New York, NY: Springer New York.

Rüttiger, L., Ciuffani, J., Zenner, H.-P., Knipper, M. (2003). A Behavioral Paradigm to Judge Acute Sodium Salicylate-Induced Sound Experience in Rats: A New 
Approach for an Animal Model on Tinnitus. Hearing Research, 180 (1-2), 39-50. DOI: 10.1016/S0378-5955(03)00075-3.

Salvi, R., Lobarinas, E., Sun, W. (2011). Behavioral Animal Models of Tinnitus, Pharmacology, and Treatment. W: A.R. Møller, B. Langguth, D. De Ridder, T. Kleinjung (red.), Textbook of Tinnitus (s. 133-144). New York, NY: Springer New York.

Sanchez, T.G., Rocha, B.C. (2011). Diagnosis of Somatosensory Tinnitus. W: A.R. Møller, B. Langguth, D. De Ridder, T. Kleinjung (red.), Textbook of Tinnitus (s. 429-433). New York, NY: Springer New York.

Schaette, R., Kempter, R. (2006). Development of Tinnitus-Related Neuronal Hyperactivity through Homeostatic Plasticity after Hearing Loss: A Computational Model. The European Journal of Neuroscience, 23 (11), 3124-3138. DOI: 10.1111/j.1460-9568.2006.04774.x.

Schaette, R., McAlpine, D. (2011). Tinnitus with a normal Audiogram: Physiological Evidence for Hidden Hearing Loss and Computational Model. The Journal of Neuroscience, 31 (38), 13452-13457. DOI: 10.1523/JNEUROSCI.2156-11.2011.

Schaette, R., Turtle, Ch., Munro, K.J. (2012) Reversible Induction of Phantom Auditory Sensations through Simulated Unilateral Hearing Loss. PLoS One, 7 (6), e35238. DOI: 10.1371/journal.pone.0035238.

Schecklmann, M., Vielsmeier, V., Steffens, Th., Landgrebe, M., Langguth, B., Kleinjung, T. (2012). Relationship between Audiometric Slope and Tinnitus Pitch in Tinnitus Patients: Insights into the Mechanisms of Tinnitus Generation. PLOS ONE, 7 (4), e34878. DOI: 10.1371/journal.pone.0034878.

Sedley, W., Gander, P.E., Kumar, S., Oya, H., Kovach, C.K., Nourski i in. (2015). Intracranial Mapping of a Cortical Tinnitus System using Residual Inhibition. Current Biology, 25 (9), 1208-1214. DOI: 10.1016/j.cub.2015.02.075

Sedley, W., Friston, K.J., Gander, P.E., Kumar, S., Griffiths, T.D. (2016). An Integrative Tinnitus Model Based on Sensory Precision. Trends in Neurosciences, 39 (12), 799-812. DOI: 10.1016/j.tins.2016.10.004.

Skarżyński, H., Rogowski, M., Bartnik, G., Fabijańska, A. (2000). Organization of Tinnitus Management in Poland. Acta Oto-Laryngologica, 120 (2), 225-226. DOI: 10.1080/000164800750000973.

Stein, A., Wunderlich, R., Alva Engell, P.L., Wollbrink, A., Shaykevich, A., Kuhn, J.T., Holling, H., Rudack, C., Pantev, Ch. (2016). Clinical Trial on Tonal 
Tinnitus with Tailor-Made Notched Music Training. BMC Neurology, 16 (1), 38. DOI: 10.1186/s12883-016-0558-7.

Turner, J.S. jr (1990). Auditory Dysfunction: Tinnitus. W: H.K. Walker, W.D. Hall, J.W. Hurst (red.), Clinical Methods: The History, Physical, and Laboratory Examinations. Boston: Butterworths. Pobrano z: https:/www.ncbi.nlm.nih. gov/books/NBK226/ (2.04.2021).

Turner, J.G., Brozoski, T.J., Bauer, C.A., Parrish, J.L., Myers, K., Hughes, L.F., Caspary, D.M. (2006). Gap Detection Deficits in Rats with Tinnitus: A Potential Novel Screening Tool. Behavioral Neuroscience, 120 (1), 188-195. DOI: 10.1037/0735-7044.120.1.188.

Udupi, V.A., Uppunda, A.K., Mohan, K.M., Alex, J., Mahendra, M.H. (2013). The Relationship of Perceived Severity of Tinnitus with Depression, Anxiety, Hearing Status, Age and Gender in Individuals with Tinnitus. International Tinnitus Journal, 18, 29-34. DOI: 10.5935/0946-5448.20130005.

Weisz, N., Hartmann, T., Dohrmann, K., Schlee, W., Noreña, A. (2006). High-Frequency Tinnitus without Hearing Loss Does Not Mean Absence of Deafferentation. Hearing Research, 222, 108-114. DOI: 10.1016/j.heares.2006.09.003.

Wiegrebe, L., Kössl, M., Schmidt, S. (1996). Auditory Enhancement at the Absolute Threshold of Hearing and Its Relationship to the Zwicker Tone. Hearing Research, 100 (1-2), 171-180. DOI: 10.1016/0378-5955(96)00111-6.

Williams, M., Hauptmann, Ch., Patel, N. (2015). Acoustic CR Neuromodulation Therapy for Subjective Tonal Tinnitus: A Review of Clinical Outcomes in an Independent Audiology Practice Setting. Frontiers in Neurology, 6, 54. DOI: 10.3389/fneur.2015.00054.

Yang, S., Weiner, B.D., Zhang, L.S., Cho, S.-J., Bao, S. (2011). Homeostatic Plasticity Drives Tinnitus Perception in an Animal Model. Proceedings of the National Academy of Sciences, 108 (36), 14974-14979. DOI: 10.1073/ pnas. 1107998108 .

Ying, Y.-L.M, Arriaga, M.A. (2011). Tinnitus and Ménière's Disease. W: A.R. Møller, B. Langguth, D. De Ridder, T. Kleinjung (red.), Textbook of Tinnitus (s. 311-316). New York, NY: Springer New York. 


\title{
TINNITUS - SELECTED MODELS OF PHANTOM SOUND PERCEPTION
}

\begin{abstract}
Tinnitus ("ringing in the ears") is sometimes described as a phantom sound. The phenomenon consists of the perception of a sound of various quality (ringing, hissing, buzzing or a permanent tone) that has no external source and is believed to be the consequence of the nervous system activity. Millions of people perceive tinnitus, but only some to a debilitating degree. In its chronic form it is often linked to hearing problems, lowered satisfaction with life and depression. Recent approach suggests that tinnitus (perception of a sound) should be differentiate from the tinnitus disorder (perception of tinnitus accompanied by suffering).

The aim of this paper is to present a reader with the most prominent models that could be categorized into two categories - models of tinnitus and models of tinnitus disorder. Their aim is to explain the evolution and maintenance of tinnitus perception from different perspectives (physiology, neuroscience, cognitive science and psychology).
\end{abstract}

\section{Cytowanie}

Wrzosek, M. (2021). Tinnitus. Analiza wybranych modeli fantomowego dźwięku. Analiza i Egzystencja, 56 (4), 95-118. DOI: 10.18276/aie.2021.56-05. 